\title{
MICHAEL PERRY, PETER SINGER, AND QUASIMODO: PERSONS WITH DISABILITIES AND THE NATURE OF RIGHTS
}

\author{
R. George Wright ${ }^{\dagger}$
}

Michael Perry's The Idea of Human Rights ${ }^{1}$ raises important and difficult issues. One such issue, reformulated, is whether the latter half of the twentieth century has witnessed both the rise of human rights language in international law, and the erosion, if not the collapse, in the intellectual sphere of the theoretical underpinnings of human rights as traditionally understood. This is part of a broader tension, in which the advance of broadly liberal values has coexisted with increasing skepticism about the objectivity of ethics, ${ }^{2}$ freedom of the will ${ }^{3}$ and genuine moral responsibility, ${ }^{4}$ meaningfulness in a natural order, ${ }^{5}$ and the irreducibility of mind. ${ }^{6}$

$\dagger$ Professor of Law, Cumberland School of Law, Samford University. Work herein was supported by a Cumberland Research Grant for the 1998 Summer Term.

1. Michael J. Perry, The Idea of Human Rights: Four Inquiries (Oxford U Press, 1998). Further references to this text will generally be by page number.

2. As mere examples drawn from a broad range of currently popular nonobjectivist metaethical stances, see Simon Blackburn, Essays in Quasi-Realism (Oxford U Press, 1993); Allan Gibbard, Wise Choices, Apt Feelings (Harv U Press, 1990); Allan Gibbard, Normative Objectivity 19 Nous 41 (1985); John L. Mackie, Ethics: Inventing Right and Wrong (Penguin, 1977); Charles L. Stevenson, Ethics and Language (Yale U Press, 1944). For a survey of common criticisms of the idea of moral objectivity, see Alan Gilbert, Democratic Individuality ch 2 (Cambridge U Press 1990). For an interesting recent response, see Eric Blumenson, Mapping The Limits of Skepticism in Law and Morals 74 Tex L Rev 523 (1996). For discussion of the erosion of the objectivist paradigm of human rights, see Ruti Teitel, Human Rights Genealogy 66 Fordham L Rev 301, 304-05, 312 (1997).

3. See, for example, Richard Double, The Non-Reality of Free Will (Oxford U Press, 1991); Richard Double, Metaphilosophy and Free Will (Oxford U Press, 1996); Ted Honderich, A Theory of Determinism: The Mind, Neuroscience, and Life-Hopes (Oxford U Press, 1988); Ted Honderich, How Free Are You? (Oxford U Press, 1993); Michael Slote, Ethics Without Free Will 16 Soc Theory \& Practice 369 (1990). 
Perry raises the question of the intelligibility. ${ }^{7}$ Of course, this strategy offers no general guarantees. Whether a familiar idea is coherent or intelligible can in some cases be subject to prolonged, subtle dispute. And sometimes an arguably intelligible moral idea is uncontroversially implausible or disastrous, such that it is easier to indict the recommendation on its evident bad consequences, rather than worry about its possible unintelligibility. Perhaps it could even be said that any moral belief that is or should be ultimately recognized by its holder as morally unacceptable is in some sense unintelligible. In any event, we shall focus below mainly on possible or likely consequences of the gradual dissipation of the idea of human rights in Perry's sense and of the idea of the objectivity of morality in general. ${ }^{8}$ Perry concludes that

There is no intelligible (much less persuasive) secular version of the conviction that every human being is sacred; the only

4. See, for example, Galen Strawson, The Impossibility of Moral Responsibility 75 Phil Stud 5 (1994).

5. See, for example, Richard Rorty, Philosophy and the Mirror of Nature (Princeton U Press, 1979); Quentin Smith, A Natural Explanation of the Existence and Laws of Our Universe 68 Australasian J Phil 22 (1990). See also Jean-Paul Sartre, Being and Nothingness (Methuen, Hazel E. Barnes, Trans, 1966).

6. For general discussion, see, for example, Paul M. Churchland, Matter and Consciousness (MIT Press, 1984); Daniel Dennett, Brainstorms (MIT Press, 1978); Stephen C. Stich, From Folk Psychology to Cognitive Science: The Case Against Belief (Harvester Press, 1983). See also B.F. Skinner, Beyond Freedom and Dignity (Knopf, 1971).

7. Perry uses the idea of intelligibility, and of inescapability and ineliminability as well. See Perry, Human Rights at 5 (cited in note 1). The intended contrast is with such ideas as persuasiveness and even mere plausibility on the one hand, and perhaps with mere avoidance of patent self-contradiction or facial internal inconsistency on the other. The idea of the (merely) conceivable or the narrowly coherent may be synonymous with intelligibility in Perry's sense, or may be weaker.

In any event, Perry's use of the idea of intelligibility seems intended, at least in part, to reach a broad, general result, and to bypass unnecessary complications, including any need to predict future events at a cultural level, or to controversially evaluate past events. The idea seems roughly that if we can show the unintelligibility of, say, a married bachelor, we need not worry about new instances or new variations on the theme within the scope of that concept, and we need not debate historical instances, send out search parties, or await potentially surprising future events.

8. Id at 11-12. 
intelligible versions are religious. (To say that the only intelligible versions of the conviction are religious is not to say that any religious version is persuasive or even plausible). The conviction that every human being is sacred is, in my view, inescapably religious - and the idea of human rights is, therefore, ineliminably religious. ${ }^{9}$

To this, there are at least four interesting possible responses, only one of which we shall pursue herein. First, one can deny that there are any intelligible religious versions of the idea of human rights, leaving open the issue of whether any secular versions are any more intelligible. Second, one can reassert the intelligibility of secular human rights claims, perhaps through redefining one or more of the ideas of rights, human rights, religion, sacredness or inviolability, or intelligibility. ${ }^{10}$ Third, one could accept Perry's conclusion or some variant thereof and, given one's strong commitment to human rights, be therefore prompted to reexamine the adequacy of a thoroughly secular understanding of the moral or natural world. ${ }^{11}$ The fourth possibility, with which we shall herein be

9. Id.

10. For reference, consider Peter Singer, Applied Ethics 84 (Oxford U Press, 2d ed, 1993) ("We may take the doctrine of the sanctity of human life to be no more than a way of saying that human life has some special value, a value quite distinct from the value of the lives of other living things"). It is remarkably common for theorists to reject an idea as standardly defined, but to nonetheless continue using the same terminology for their new, much attenuated replacement version of the idea, on the grounds that the replacement notion is all that is realistically available, or all that is worth wanting. When crudely employed, this can involve trading illicitly, if unconsciously, on the favorable associations of the assumedly now obsolete version of the concept. In contrast, for a thoughtful and sophisticated instance, see Daniel C. Dennett, Elbow Room: The Varieties of Free Will Worth Wanting (MIT Press, 1984).

11. This would be at least vaguely akin to accepting what is traditionally known as a moral argument for the existence of God. See, for example, Robert M. Adams, The Virtue of Faith ch 10 (Clarendon Press, 1987); Richard Swinburne, The Existence of God 175-76 (Oxford U Press, 1979); Keith Ward, God, Chance and Necessity 90 (Rowman \& Littlefield, 1996). See also John Leslie, Value and Existence (Rowman \& Littlefield, 1979); John Leslie, Universes ch 8 (Routledge, 1989). A further step for anyone considering taking the argument in this direction might be to then take some position on the familiar "problem of evil." See, for example, Daniel Howard-Snyder, ed, The Evidential Argument From Evil (Ind U 
concerned, also involves accepting Perry's conclusion or something like it. This response, however, is to choose to retain one's exclusive commitment to the secular, and to therefore abandon the idea of human rights as Perry understands the term.

Important intellectual trends, as we have already suggested, underlie such a response. If one has already come to doubt any meaningfulness in nature, moral objectivity, free will, mind, and responsibility, it will hardly seem a significant further step to jettison traditional understandings of human rights. The step involved is mainly that of incurring a psychological, or perhaps a political, cost. Alone of all these gradually evaporating ideas, only the idea of human rights is still fairly widely associated with political progressivism.

In a strictly logical sense, abandoning the traditional idea of human rights is actually no further step at all, but is instead already contained within the broader abandonment of moral objectivity in general. $^{12}$ One could, no doubt, redefine the idea of a human right so as to be able to speak of human rights even in the absence of any assumed objectivity of morals. But the thinner the metaethics, the less room there can be for human rights as traditionally conceived.

A question of crucial practical importance then arises: what happens, over the long-term, when we back away from any idea of objectivity of morality in general and of objective human rights in particular? Would the general demise of belief in any objectivity of morals over time have significant consequences for particular groups, or for society in general? Would the least well off groups likely suffer disproportionately? This is, unfortunately, a complex question involving predictive matters of culture, history, psychology,

Press, 1996); Marilyn McCord Adams \& Robert Merrihew Adams, eds, The Problem of Evil (Oxford U Press, 1990).

12. Michael Perry recognizes at 5 that "[w]hile the idea of human rights is not, for those who accept it, the whole of morality, it is a fundamental part." Also see id at 28. We shall assume that traditionally, and in international law, human rights claims are thought to be morally objective in character. It is certainly possible to develop, say, an emotivist or attitude expressive and prescriptive approach to human rights, however compelling or otherwise such usages might be. We shall leave it to the emotivist theorist of human rights to decide whether it is disturbing that such human rights usages might inescapably express, by implication, religious beliefs or presuppositions. 
socialization, evolutionary biology, law, and any number of other disciplines all mutually interacting over time. It is also one on the answer to which our own society appears currently to be placing a bet. Perhaps the gradual abandonment of moral objectivity and of human rights in particular will prove liberating. ${ }^{13}$ Perhaps it will eventually turn out to simply not matter very much. ${ }^{14}$ Perhaps, on the other hand, things will turn out unattractively, at least from any current progressive standpoint. ${ }^{15}$

Perry addresses these concerns throughout the first chapter of The Idea of Human Rights. Human rights, as traditionally understood, reflect some presumably shared attribute of human beings. ${ }^{16}$ While it is possible to refer to this attribute as an aspect of the human personality, ${ }^{17}$ the relevant aspect is not so much a matter of psychology as of ascribed worth, based on the nature and status of the human in a deeply or ultimately meaningful world. ${ }^{18}$

Whether the world provides this sort of ultimate meaning, or whether we must make do with such meaning as we can ourselves construct, is central to philosophical concern since the Enlightenment. Perry formulates the question in these terms:

Am I indeed an alien, an exile, homeless, in a world, a universe, that is strange, hostile, pointless, absurd? Or, instead, is the world, finally and radically, familiar, even gracious; does the world have a point, is it a project; is the world, in that sense, meaningful: meaning-full, full of meaning rather than bereft of it (and therefore meaning-less, absurd) ? $^{19}$

Perry recognizes, of course, that meaning, and even meaningfulness in a life, can in some sense be constructed, even more or less arbitrarily. Some persons, at the extreme, live and die

13. See, for example, Richard Rorty, Postmodernist Bourgeoise Liberalism 80 J Phil 583 (1983).

14. See, for example, Jeremy Waldron, The Irrelevance of Moral Objectivity in Robert P. George, ed, Natural Law Theory: Contemporary Essays 158 (Oxford U Press, 1992).

15. See, for example, R. George Wright, Reason and Obligation ch 5 (U Press of America, 1994).

16. Perry, Human Rights at 12,13 (cited in note 1).

17. Id at 12 .

18. Id at 12-15.

19. Id at 1 (italics in the original). 
with a particular sports team with whom they may have only the most tenuous of geographical connections. ${ }^{20}$ But Perry detects a difference between a morality that somehow finds ultimate meaning in the world, and a morality that seeks to invent and impute such meaning, or its facsimile. ${ }^{21}$ Perry refers to the former as conceiving of life's meaning in a strong or objective sense. ${ }^{22}$

Is it possible, though, to adequately defend the substance of human rights injunctions without relying on the idea of strong or objective meaningfulness? Perry considers two kinds of attempts to accomplish this. These he refers to respectively as the definitional strategy ${ }^{23}$ and the self-regarding strategy. ${ }^{24}$ In Perry's view, neither of these two attempts is successful.

The definitional strategy seeks to arrive at, and sufficiently validate, human rights claims through a proper understanding of the bare idea of morality itself. On this view, morality itself implies, or logically requires, the ideas of impartiality, of universality, and of equality of concern and respect. ${ }^{25}$ To count merely some, but not others, and to care about some, but not others, is not to endorse a narrow morality, but to fail to embrace morality at all. Perry argues in response that this approach fails to address the question of why one should embrace the moral point of view in the first place. ${ }^{26}$ Once one's metaphysics becomes too thin, embracing universal, impartial morality, as opposed to the interests of only one's own group, seems arbitrary. ${ }^{27}$ Perry urges that " $[t]$ he moral point of view is itself in direct need of justification, especially in a world-our world, the real world - that is often fiercely partial/local rather than impartial/ universal.".28

20. One thinks first of English soccer hooligans, but one could also think of more proximate, and thankfully more socially benign, such cases.

21. Id at 29.

22. Id.

23. Perry, Human Rights at 29-30.

24. Id at 32-33.

25. Id at 30 .

26. Id.

27. Id at 31. Of course, it would be odd to ask for a moral reason for embracing morality, but it hardly seems odd to ask for a justification grounded in broadly prudential or other forms of reason.

28. Id at 31 (italics in the original). 
The self-regarding strategy seeks to arrive at the substance of human rights claims indirectly. The idea is that it is good for one's self or one's group that certain things be done or not done for or to every human being. ${ }^{29}$ Perry argues in response that this approach partakes more of a non-aggression pact among potential mutual threateners than an adequate ground for any universal morality. ${ }^{30}$ Realistically, there is little reason to suppose that we will some day need the cooperation or the forbearance of either the victims or the perpetrators of human rights violations in, say, the Balkans. ${ }^{31}$ Perry observes further that "even if you live among us but are, say, severely handicapped, we might not think that you have anything to offer us. ${ }^{\prime 32}$ Perry concludes that the self-regarding strategy is no more successful than the definitional strategy in finessing the question of human rights and their reliance on an objectively, ultimately meaningful world.

Perry thus concludes more broadly that the adequate intellectual defense of human rights, if one is possible, requires belief in an objective moral order and an ultimately meaningful world. This, Perry hastens to note, does not mean that it is somehow impossible or inconsistent to deny objective morality and yet vigorously defend the human rights of some, indeed all, other persons. ${ }^{33}$ But this admitted possibility still leaves open questions of motivation and of consistency. Institutions, including that of human rights, do not survive merely because it is possible to believe in them, or because different sorts of persons currently do so believe. Perry recognizes that some writers, such as Richard Rorty, have been led by their distrust of objectivist metaethics to simply reject the idea of human rights in its traditional sense. ${ }^{34}$ Perry asks in contrast whether it seems responsible to defend human rights, perhaps through killing and dying, based merely on our own sentiments, preferences, stories,

29. Perry, Human Rights at 32 (cited in note 1).

30. Id.

31. Id at 33 .

32. Id.

33. Id at 35 .

34. Id at 37-38 (citing Richard Rorty, Human Rights, Rationality, and Sentimentality in Steven Shute \& Susan Hurley, eds, On Human Rights: The Oxford Amnesty Lectures 116 (1993)). 
and conventions apart from purportedly objective, transcultural grounds. ${ }^{35}$

The consequences of abandoning the standard logic of human rights, along with all other purportedly objective moral claims, is of concern to Perry, and should plainly be of concern to us all. As philosophers tend toward abandoning the idea of human rights and objective morality more generally, ${ }^{36}$ the question may well become less purely academic, and may eventually come to impinge upon political and legal practice. ${ }^{37}$

Rather than attempt to address this question in global fashion, let us more manageably consider it from a single, narrower perspective where important values are directly at stake and in which our intuitions are widely shared and fairly clear. Specifically, let us consider what happens when we collectively back away from putatively objective human rights claims, or other putatively objective moral claims, regarding persons with disabilities. ${ }^{38}$

One might conceivably object to this approach on the grounds that the relevant rights of persons with disabilities cannot technically be human rights, but only rights of those humans, more narrowly, with disabilities. Admittedly, there does seem to be some difference between the rights of persons with disabilities, precisely in that capacity, and, let us say, a broader human right to a name, or to food. ${ }^{39}$ It would be artificial at best to say that the latter rights pertain

35. Perry, Human Rights at 37-39 (cited in note 1).

36. For discussion, see, for example, Susan Mendus, Human Rights in Political Theory 43 Pol Studies 10, 10-11, 14 (1995).

37. Id at 17.

38. Perry explicitly raises the question of the moral status of severely disabled persons, and other persons having little with which to bargain or threaten, at 33 . He also briefly refers to "abandonment of small children" at 22, a subject we shall touch upon below in connection with our discussion of the views of Peter Singer.

39. For an extended discussion of subsistence rights, see Henry Shue, Basic Rights: Subsistence, Affluence and US Foreign Policy (Princeton U Press, 2d ed, 1996). For a relevant international legal reference to the right to a name, see Albert P. Blaustein, Roger S. Clark \& Jay A. Sigler, eds, Human Rights Sourcebook 202, 203 (Paragon House, 1987) (quoting Principle 3 of the Declaration of the Rights of the Child (1959), G.A. Res. 1386 (14), 14 G.A.O.R. Supp (no 16) at 19, UN Doc A/4354 (1959) ("The child shall be entitled from his birth to a name and a nationality")). For references to the international legal rights of persons with disabilities, see id at 217-18 (quoting Declaration on the Rights of Disabled 
only to humans who do not have a name, or who need food, and not to humans generally. As well, it is doubtful that every moral right we ascribe to a disabled person, in just that capacity, will itself amount to a human right. A disabled person in an advanced economy may have a moral right to access to something like a kneeling bus, but whether this moral right must also be thought of as a human right is at least debatable. ${ }^{40}$

On the other hand, certain moral rights held by disabled persons, precisely as disabled persons, clearly qualify as putative human rights. Whatever one thinks about the merits of such claims, or about the status or value of human rights in general, an asserted right not to be suffocated, abandoned, publicly flogged, or denied all available employment because one is disabled is a claim within the scope of human rights. To hold otherwise would disregard the traditional understanding of the scope of human rights, and disqualify uncontroversially central human rights claims. Clearly, human rights can be violated through acts that aim not only at what all humans currently share, but essentially at one's particular disfavored ethnic status, religion, gender, and so on. Michael Perry describes, for example, human rights violations aimed explicitly at particular sorts of persons, as that sort of person, as in the case of Serbian atrocities against Moslems or Moslem women. ${ }^{41}$ Such actions are not thereby removed from the scope of putative human rights violations.

How, then, does the gradual ebbing of the idea of moral objectivity, and of human rights in particular, work itself out in practice in the case of persons with disabilities? Overall, the best theoretical exemplar of this process may be the work of the applied moral philosopher Peter Singer. Singer thus may provide the most useful response, in our context, to the work of Michael Perry. Singer is a leading academic philosopher who has addressed issues of metaethics, of the possibility and scope of moral and legal rights of

Persons (1975), G.A. Res. 3477 (30), 30 UN Doc A/10034 (1975) ("Disabled persons have the inherent right to respect for their human dignity"). ("Disabled persons are entitled to the measures designed to become as self-reliant as possible")).

40. The Americans with Disabilities Act of 1990, 42 USCA $\S 12101$ (West, 1995) affects such public accommodations. Id at $\S 12182$.

41. Perry, Human Rights at 28 (cited in note 1). 
disabled persons, of normative ethics in general, and of practical problems associated with his own metaethical and normative views. ${ }^{42}$

His work is particularly useful for several reasons. First, he is sympathetic to the interests of disabled jobseekers, ${ }^{43}$ so his views cannot be simply dismissed as irrelevant, marginal, and unilluminating. Second, he endorses positions that set our particular inquiry in motion. He takes a position diametrically opposed to Perry in that he entirely sets aside any sort of religious element in ethics, at either the metaethical or normative levels. ${ }^{44} \mathrm{He}$ entirely rejects the idea of moral objectivity in ethics, ${ }^{45}$ in favor of some form of moral noncognitivism, ${ }^{46}$ a mainstream contemporary metaethical position. ${ }^{47}$ At the normative ethical level, he endorses a particular form of utilitarianism, ${ }^{48}$ and again contrary to Perry, rejects the idea of moral rights in general and human rights in particular, ${ }^{49}$ though here with certain qualifications. ${ }^{50}$ Third and finally, Singer writes with exceptional clarity, candor, subtlety, and with unusual attention to problems of practical implementation. Even where it is possible to criticize Singer for seeking to finesse, rather than resolve, an unattractive implication of his views, Singer is open and forthright

42. Professor Singer is an exceptionally prolific scholar, but the single most convenient and comprehensive treatment of all of these matters can be found in Peter Singer, Practical Ethics (Cambridge U Press, 2d ed, 1993).

43. Id at 52-53.

44. Id at Introduction.

45. Id at 7-8.

46. Id.

47. See, for example, Gibbard, Wise Choices (cited in note 2); Charles L. Stevenson, Ethics and Language (Yale U Press, 1944).

48. Singer, Practical Ethics at ch 1, 94 (cited in note 42).

49. Id at ch $1,94,96$. Singer is perhaps best known for his concern for persons as opposed to genetic human beings. This is of course important in some contexts, but not in ours. Michael Perry generally adopts the standard moral and legal terminology of "human" rights.

50. Id at 172. Arguably, a utilitarian must rely on some sort of rights conception in establishing who or what counts, and for how much, for utilitarian purposes; one cannot answer these questions by reference to maximizing utility without begging the question. And at various points, as we shall see, Singer is tempted to adopt something that looks like a moral right, even if this remains outside his "ideal" theory, for the sake of avoiding possible bad consequences of trying under less than ideal circumstances to implement a purer preference utilitarian theory. See, for example, id. 
about his strategy. His work thus provides a useful foil for Perry and an excellent case study for our purposes.

Let us first establish Singer's views on disability in the narrow context of job discrimination and access to public accommodations. Here, Singer's preferred outcomes track the logic of statutes such as the Americans with Disabilities Act ${ }^{51}$ and the Rehabilitation Act. ${ }^{52}$ Singer endorses a principle of nondiscrimination ${ }^{53}$ against disabled persons on grounds not deemed relevant ${ }^{54}$ to the job or service at issue. Which sorts of disabilities are genuinely relevant to which particular jobs is sometimes controversial, ${ }^{55}$ but Singer clearly empathizes with disabled jobseekers. ${ }^{56}$

Singer refers to discrimination against disabled persons in terms of a "confusion" between "factual equality" and "moral equality." 57 He may mean here that the distinction between disability and nondisability implies some sort of factual inequality, but not moral inequality, between persons. His point may thus be that some forms of factual inequality may be relevant to an applicant's job qualifications, whereas others will not, and that we should not devalue or undercount the real interests of persons with disabilities. ${ }^{58}$

51. See generally the Americans with Disabilities Act (cited in note 40).

52. See generally the Rehabilitation Act of 1973, 29 USCA $\S 701$ (West, 1985 \& Supp 1998).

53. Singer, Practical Ethics at 52 (cited in note 42).

54. Id at 52, 53 .

55. Distinguishing between a person with a disability who could perform the job with reasonable accommodation and a person whose disability renders her unqualified is often a crucial determination. For discussion, see, for example, Den Hartog $v$ Wasatch Acad., 129 F3d 1076 (1997); Vande Zande $v$ State of Wisc, 44 F3d 538 (1995).

56. Singer, Practical Ethics at 52 (cited in note 42) ("Even today, some businesses will not hire a person in a wheelchair for a job that she could do as well as anyone else. Others seeking a salesperson will not hire someone whose appearance is abnormal, for fear that sales will fall. (Similar arguments were used against employing members of racial minorities; we can best overcome such prejudices by becoming used to people who are different from us.")).

57. Id.

58. Casual references to an applicant's ability to do a job, with or without reasonable accommodations, of course need to be clarified in some fashion. Qualifications are always relative to those of possible competing applicants, or to automating the work process, and refer not to the mere ability to do certain physical or mental tasks, but to do them with a certain degree of success, or with a certain 
Singer's argument is then that equal membership in the community, and the broader underlying principle of equal consideration of the interests of disabled persons, require not mere equality of opportunity, ${ }^{59}$ but "affirmative action" 60 in favor of disabled persons. Actually, this conclusion seems mainly a matter of preferred terminology. Singer's distinction here depends upon a thin, formalistic view of equality of opportunity, under which physically denying access to public accommodations ${ }^{61}$ and denying placement in mainstream classes ${ }^{62}$ is somehow assumed to be compatible with equal opportunity, hence requiring "affirmative action" as a remedy. ${ }^{6}$

In any event, Singer concludes that more should be spent, ${ }^{64}$ in general, for the benefit of people with disabilities in these contexts than on non-disabled persons. This is said to follow from a general moral decisionmaking process of empathetically identifying with and considering $^{65}$ the interests of all affected persons equally. ${ }^{66}$ This corresponds to what Michael Perry refers to as the definitional strategy. The needs of the disabled should evoke more resources, even on the basis of (merely) equal consideration of their interests, because the relevant needs ${ }^{67}$ of the disabled will often be "very

error rate, or within a certain time, based on a certain degree of employer investment and supervision, all as translated into something like employee productivity, profit maximization, or avoidance of company bankruptcy. Id.

59. Id at 53.

60. Id.

61. Id.

62. Id.

63. Singer, Practical Ethics at 53 (cited in note 42).

64. At some point, of course, a decision must be made as to which of these costs should be borne by the taxpayers, and which by employers or facility owners, perhaps to be partially or completely passed along to customers or users.

65. Id.

66. Id. For a sampling of recent discussions of the possibility or the proper scope of the general redistribution of resources in favor of persons with disabilities, see Ronald Dworkin, What Is Equality? Part 2: Equality of Resources 10 Phil \& Pub Aff 283, 296, 300, 339 (1981); Gregory S. Kavka, Disability and the Right to Work 9 Soc Phil \& Pol'y 262 (1992); Jeff McMahon, Cognitive Disability, Misfortune, and Justice 25 Phil \& Pub Aff 3 (1996); David Wasserman, Disability, Discrimination, and Fairness 13 Phil \& Pub Pol'y 7 (1993).

67. Singer, Practical Ethics at 53 (cited in note 42). 
central"68 to their lives, and will therefore receive "much greater weight than more minor needs of others." plausible on any utilitarian, and many nonutilitarian, theories. Singer's use of the idea of something's being "central" to a life need not trouble us. Doubtless something can be 'central' to a life in a utilitarian sense, but different sorts of philosophers may address the idea of centrality in different ways.

Having introduced Singer's general approach to the rights of disabled persons, let us consider, for the sake of concreteness, the particular case of Victor Hugo's Quasimodo. ${ }^{70}$ The concreteness of such an inquiry has certain virtues. Hugo writes that "Quasimodo, one-eyed, hunchbacked, and bowlegged, could hardly be considered as anything more than almost." approach treats Quasimodo as more than an "almost" is, we may suggest, an important test. Certainly, the major Parisian political and religious institutions, along with the general Parisian populace, treat him as an almost. How far we have come, however, from late medieval Paris is occasionally subject to question. There are certainly contemporary horror stories to tell of the treatment of persons with disabilities. ${ }^{72}$

68. Id.

69. Id.

70. Textual references will be to Victor Hugo, The Hunchback of Notre Dame (Signet Penguin, Walter J. Cobb \& Phyllis La Farge, Trans, 1965).

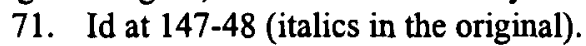

72. Erving Goffman, for example, recounts second hand:

I remember ... a man at an open-air restaurant in Oslo. He was much disabled, and he had left his wheel-chair to ascend a rather steep staircase up to the terrace where the tables were. Because he could not use his legs he had to crawl on his knees, and as he began to ascend the stairs in this unconventional way, the waiters rushed to meet him, not to help, but to tell him that they could not serve a man like him at that restaurant, as people visited it to enjoy themselves and have a good time, not to be depressed by the sight of cripples.

Erving Goffman, Stigma: Notes On the Management of Spoiled Identity 120 (Simon \& Schuster, 1986). Or consider an even more recent example, occurring in the US, two months after the effective date of the ADA's public accommodations section:

"[J]ournalist John Hockenberry... . had paid $\$ 60$ for his ticket and had checked in advance that the theater was accessible. But when he 
Quasimodo certainly fares reasonably well on Singer's approach, insofar as he applies for employment as a bellinger, or seeks to use public accommodations. Whether Quasimodo fares equally well in other contexts, based on Singer's principle of equal consideration of interests, is, however, open to greater doubt, as we shall see below. Ultimately, Michael Perry's approach corresponds more closely with our considered judgments on the moral decisionmaking process than does that of Peter Singer, even granting the subtlety of the latter.

Consider first the young version of the congenitally deformed and parentally abandoned Quasimodo. $\mathrm{He}$ is described by one observer as "a beast, an animal-the offspring of a Jew and a sowsomething, at any rate, which is not Christian, and which must be thrown into the river or fire."73 Quasimodo's "head was so deformed! It was nothing but a forest of red hair, one eye, a mouth, and a few teeth. The eye was weeping; the mouth was crying; and the teeth seemed to want only to bite." ${ }^{74} \mathrm{He}$ "was born one-eyed, hunchbacked, and lame." 75

Of course, consigning the young Quasimodo to the river or fire was not a unanimous public recommendation. Among his mixed reviews were these:

'What is the world coming to,' said Jehanne, 'if that's the way they make children nowadays?'

'I don't know much about children,' resumed Agnes, 'but it must be a sin to look at this one.'

'It's not a child at all, Agnes. It's a deformed ape,' observed Gauchère.

showed up, the theater manager refused to help seat him. 'You are a fire hazard, sir,' the manager complained."

Joseph P. Shapiro, No Pity: People With Disabilities Forging a New Civil Rights Movement 331 (Times Books, 1994). The odd combination here of formality or superficial politeness of address with the suggestively un-Kantian content-"You are a fire hazard"-reveals much of our continuing ambivalence toward persons with disabilities.

73. Hugo, Hunchback at 140 (cited in note 70).

74. Id at 141 .

75. Id at 142. While Quasimodo had "much difficulty" learning to speak in any event, his deafness arose later, only as a result of his close exposure to the bells of Notre Dame. See id at 149-50. 
'It's a miracle,' said Henriette la Gaultière. ${ }^{76}$

The overall public sentiment, however, seems reasonably clear. Quasimodo, at least at the time of his exposure for possible adoption or at some even earlier time, may well be profoundly vulnerable on any straightforward utilitarian calculus.

For his part, Peter Singer correctly observes that "[a] week-old baby is not a rational and self-conscious being, and there are many nonhuman animals whose rationality, self-consciousness, awareness, capacity to feel, and so on, exceed that of a human baby a week or a month old." "77 Singer elaborates:

Newborn babies cannot see themselves as beings who might or might not have a future, and so cannot have a desire to continue living. ${ }^{78}$ For the same reason, if a right to life must be based on the capacity to want to go on living, or on the ability to see oneself as a continuing mental subject, a newborn baby cannot have a right to life. Finally, a newborn baby is not an autonomous being, capable of making choices, and so to kill a newborn baby cannot violate the principle of respect for autonomy. ${ }^{79}$

76. Id at 140. Thus while the clear majority seem to find this "pretended orphan" to be demonic, deserving of the flames, and otherwise fated for "the greatest calamities," at least one person steps forward to adopt the foundling. Id at 142.

77. Singer, Practical Ethics at 169 (cited in note 42).

78. Actually, this may underplay the reality of what might be called instinctive desires. More exotically, let us assume that it is physically possible for beings to live in and be aware of different numbers of physical dimensions and, less controversially, that I can no more imagine what it would be like to exist in different numbers of dimensions than an infant can imagine her own death or nonexistence. Isn't there still a real sense in which I might desire to remain in what appears to be my familiar four dimensional space-time manifold rather than be somehow promoted to an admittedly utterly unenvisionable, if somehow less constrained, higher dimensional existence? Not all desires, it would seem, imply a current state of affairs and an imaginable alternative. As it turns out, our actual dimensional status is currently under some professional uncertainty. See, for example, John D. Barrow, Theories of Everything 101 (Oxford U Press, 1991) (string theory as, on some versions, predicting up to 22 additional spatial dimensions).

79. Singer, Practical Ethics at 171 (cited in note 42). For Singer's own more nuanced approach to different sorts of principles of autonomy, see id at 100 . 
We are, of course, interested in the possible disposition of Quasimodo beyond newborn status. It is open to Michael Perry to ask whether the month old child is "neighbor." Extending in time the autonomy test cited by Singer is a matter of cognitive developmental psychology. Singer thus observes quite sensibly that

It would, of course, be difficult to say at what age children begin to see themselves as distinct entities existing over time. Even when we talk with two or three year old children it is usually very difficult to elicit any coherent conception of death, or of the possibility that ... the child herself ... might cease to exist. No doubt children vary greatly in the age at which they begin to understand these matters. ${ }^{80}$

On Singer's own form of utilitarianism, which focuses on equal consideration of the interests or preferences of all affected parties, there can really be no directly arrived at, straightforward prohibition on the killing of children or adults. ${ }^{81}$ Even if Singer can reach the right result, we must ask whether Michael Perry can do so in a less ad hoc fashion.

Singer must first offer some convincing general account of what sorts of things count, and for how much, in the utilitarian calculus. Why do plans, interests, projects, or even preferences and desires count directly at all, to the extent they are not reducible to feelings of some sort of pleasure or pain? Does a distinct selfconsciousness or self-awareness count along with, if not more than, sensations or memories of pleasure or pain? Why doesn't Singer's approach in this respect embody, ironically, a kind of speciesist or cognitivist bias, reflecting distinctively personal attributes, at the obvious, systematic expense of animals? Is this perhaps just a vestige of some sort of discredited traditional hierarchy of being?

80. Id at 17i. One disturbing element of the view discussed by Singer at this point is the possibility that a young child's right to continue to live might depend upon the degree to which she has benefited from, or been denied, a cognitively stimulating upbringing. A child with a philosophical, or perhaps merely morose, caregiver might acquire a right to life relatively early, and a relevantly deprived child only much later. In the worst cases, the existence or not of a right to continue to live would directly reflect parental wealth and poverty.

81. Id at 172-73. For a concise critique of utilitarianism generally along these lines, see, for example, James W. Nickel, Making Sense of Human Rights 92-93 (U Cal Press, 1987). 
Let us consider a specific example. Does a human's 80 utiles of long-term project fulfillment outweigh 100 utiles of a non-human animal's mere physical pain? Is Singer just arbitrarily exalting the moral status of what his readers are good at? No doubt we negatively value the frustration of our plans. The term 'frustration,' however, is deeply ambiguous. Sometimes frustration, in a broad sense, is not even felt or experienced. Why should any utilitarian care about frustration in any sense, except insofar as someone's broadly defined pleasure or pain is somehow affected? It is admittedly possible for someone to find pain undesirable, or perhaps even desirable, and thus to evaluate or react to pain or pleasure. But these sorts of desires merely re-raise the question-are they in turn based on some sort of more basic conscious pain or pleasure, or some other conscious state? It is hard to see why a 'frustration' of one's plans that is never sensed or brought to awareness, and that has no emotional effect, should count, at least directly, on any utilitarian calculus.

Let us simply assume nonetheless that Singer, as a preference utilitarian, has developed a fully defensible general account of what should and should not count for utilitarian decisionmaking. What should Singer then say in particular of disabled or deformed and widely unappealing children, including Quasimodo? Are they to be embraced within Michael Perry's universal fraternity? Let us suppose first that the death of Quasimodo at a point during his first several years of life would likely have causally led to the birth of a "replacement" child without Quasimodo's deformities, and with much greater appeal to the child's parents and to the public in general. ${ }^{82}$ What does the weighting and summation of the various relevant interests, preferences, and desires suggest as a permissible, if not mandatory, course regarding Quasimodo?

We can easily imagine a scenario in which there is no parental or other family interest favoring Quasimodo's continued existence, and in which the general public finds him repugnant, fear-inducing, burdensome, or demonic. For at least the first several years of his life, Quasimodo may have had no grasp of his own mortality, no long-term projects, no aspirations, no social relationships, and a net

82. Singer raises the idea of such cases, and briefly discusses them in Practical Ethics at 186 (cited in note 42). 
balance of pain and conscious frustration over enjoyment. Especially when we add in the assumed better prospects of a "replacement" child, we can well imagine a utilitarian calculus that permits, if it does not require, the appropriately carried out death of Quasimodo.

Singer rightly insists that we cannot reach such conclusions casually, or without substantial qualification. He notes that "infants appeal to us because they are small and helpless, and there are no doubt very good evolutionary reasons why we should feel protective towards them." 84 Quasimodo, of course, generally fails to inspire affection, given his unappealing appearance, whatever his size and degree of helplessness. ${ }^{85}$ Evolutionary tendencies commonly do little to counteract cultural practices that clearly underprotect the basic interests of children. ${ }^{86}$

83. We are of course assuming here that for purposes of the relevant moral calculus, it is possible that one person, whether of finite or infinite moral importance, can "replace" another. This would be akin to a process of removing one complicated term from a mathematical equation, and substituting another.

84. Id at 170.

85. If smallness of size and helplessness were the only factors at work here, organizations concerned with endangered species would emphasize their associations with scarce endangered bugs, rather than Giant Pandas.

86. See, for example, Robert Wright, The Moral Animal: Evolutionary Psychology and Everyday Life 104 (Pantheon Books, 1994). Doubtless there are reasonably interesting evolutionary explanations for virtually all common behavior, moral and immoral, and for their opposites. No doubt some explanation could be given in terms of genetic survival advantage for self-consciousness, or our ability to deploy quantum mechanics. Unfortunately, this genetic winnowing process does not seem to lead to entirely satisfactory results. The behavior, for example, of noncustodial fathers with child support obligations tends to vary remarkably and may not be improving over time. More generally, it is difficult to believe that evolutionary forces and moral principle counsel the same tradeoffs among the interests of one's self, close relatives, non-relatives, and strangers, including those not in a position to confer evolutionary benefits on us. It is unclear in particular how evolutionary tendencies especially enhance the quality of life of the outcast and the oppressed. Thus the project of creating an "evolutionary left," to counteract the Herbert Spencers and William Graham Sumners of the world, seems doubtful at best. Reciprocal altruism and repeatable patterns of cooperation tend to bypass those not in a position to directly or indirectly help us or those we care about. For background, see Robert Trivers, the Evolution of Reciprocal Altruism 46 Q Rev Biol 35 (1971) and more generally, Robert Axelrod, The Evolution of Cooperation (Harv U Press, 1984). For a brief but intriguing discussion by a non- 
Singer also notes that young children are generally incapable of the mens rea elements of serious crimes, and therefore cannot be thought to "deserve" to die, as might an adult. ${ }^{87}$ In contrast, Michael Perry might ask whether the utiles of hatred toward Quasimodo deserve to count (positively) at all, at any level. As well, Singer argues that "where rights are at risk, we should err on the side of safety." controversial prior rights assignments. Just as some utilitarians and others would argue that even innocent children and adults do not have a genuine moral right to not be killed, some might argue that one or more crucial rights at stake in such cases may actually be held by persons adversely affected by the child. If there are rights claims on both sides, a wish to err on the side of protecting rights will not be of much assistance. Singer's idea may instead be that a right or interest in physical safety usually outweighs competing interests. It is not clear, though, why Singer would believe this of relatively young children.

Singer concludes that "[w]e should certainly put very strict conditions on permissible infanticide; but these restrictions might owe more to the effects of infanticide on others than to the intrinsic wrongness of killing an infant." ${ }^{89}$ Doubtless the indirect effects of

specialist polymath, see George Ellis, Before the Beginning 108-09 (Marian Boyars Pub, 1993).

87. Singer, Practical Ethics at 170 (cited in note 42).

88. Id at 172. Singer's reference to rights should be clarified. He writes earlier that "I am not convinced that the notion of a moral right is a helpful or meaningful one, except where it is used as a shorthand way of referring to more fundamental moral considerations." Id at 96. By "more fundamental moral considerations," Singer presumably means not moral duties and obligations, but interests, desires, and preferences, as properly counted and weighed. As a practical matter, to consistently disavow the use of the idea of a moral right, while other schools of thought still use such terminology, is still to place oneself at a rhetorical disadvantage. For background, see, for example, Mark Tushnet, An Essay On Rights 62 Tex L Rev 1363 (1984); Duncan Kennedy, A Critique of Adjudication: Fin de Siecle 335 (Harv U Press, 1997); id at 334 ("Having lost one's faith in rights discourse is perfectly consistent with, indeed often associated with, a passionate belief in radical expansion of citizen rights against the state").

89. Id at 173. Once indirect effects are taken into account, of course, it becomes possible for any utilitarian to prohibit post-birth killings, or killings after a month, or at any other point, as Singer argues. The matter becomes quickly 
killing children are multiple and difficult to predict, even if we ignore aggregate or long-term consequences. But it is difficult to see how paying special attention to the interests, preferences, or desires of other persons would help Quasimodo at any age. As we shall see further below, ${ }^{90}$ Quasimodo at any age is widely and deeply, if quite absurdly, detested. Michael Perry can argue at this point that these popular feelings simply should not morally count, based on the nature or character of these feelings. A surprising number of persons believe, however erroneously, that their basic interests are somehow undermined by Quasimodo's continued existence. Quasimodo himself, particularly as a child, can offer at most only a modest counterweight to those perceived interests. Perhaps the least unavailing utilitarian case for allowing the young Quasimodo to continue to live has, perhaps disturbingly, less to do with Quasimodo and his life than with the broader historical battle against superstition and oppression in general. On the most favorable utilitarian analysis, Quasimodo's life might well hinge on whether he can be turned into a useful object lesson.

Singer explicitly recognizes, and indeed insists upon, the difference between a world in which his or any other set of moral rules is implemented flawlessly, and our second-best world of imperfect information, cognitive and other biases, self-indulgence, desensitization, public bads, slippery slopes, cascade effects, chaos theory, and unpredicted long-term consequences. He therefore raises the possibility of establishing a remarkable gulf between the technically "correct" moral status of infanticide and the more restrictive way the law of homicide should continue to treat infanticide and the killing of older children generally. ${ }^{91}$ Alternatively, Singer argues, there may well be an important practical difference here between what R.M. Hare has referred to as the "critical" and "intuitive" levels of morality itself." What is

swallowed up in speculative empirical uncertainties. For more extensive discussion, see Michael Tooley, Abortion and Infanticide (Clarendon Press, 1983).

90. See notes 98-101.

91. Singer, Practical Ethics at 172 (cited in note 42).

92. Id at 172, 92-93 (citing Richard M. Hare, Moral Thinking: Its. Levels, Method and Point (Oxford U Press, 1981)). Hare suggests, id at 43, that "the critical thinker considers cases in an act-utilitarian or specific rule-utilitarian way, 
permissible at the critical (or "study carrel") level of morality need not also be permitted at the intuitive (or "mass applicability") level. Thus Singer can, as often as he wishes, reach the same final moral recommendation as Michael Perry.

Relying on either of these distinctions, however, creates its own problems. It is difficult to compartmentalize dramatically different and practically irreconcilable moral and legal approaches to, let us suppose, the parental killing of a (replaceable) one or two year old. In some such cases, Singer's moral philosophy may well conclude that such a killing is, all things considered, not morally wrong. Yet the law, however forgiving it may be of the killing of a one or two year old under many difficult circumstances, will also want to retain the option of severity in some other cases. Expecting a society to say that the dispatching of a particular two-year-old was both really not morally objectionable and yet deserving of a prison term is probably to expect too much.

This is not a matter of logical inconsistency, as though we had classified a crime as both malum prohibitum and malum in se. Rather, it is difficult to imagine a stable, long-term cultural practice

and on the basis of these he selects ... general prima facie principles for use, in a general rule-utilitarian way, at the intuitive level." See also Practical Ethics at 245-46 (cited in note 42), in which Singer somewhat disturbingly discusses a strategic decision to not publicly advocate what he views as the "critically" correct moral standard of poverty relief, and to instead advocate some "intuitive," otherwise incorrect, lower standard, lest publicizing the higher standard backfire by inspiring less public responsiveness to the problem of poverty. This sort of benignly intended duplicity, vaguely akin to a Socratic "noble lie" embodying a deeper truth, is "always a possibility" on Singer's account. Id at 245 . We must then wonder whether it really maximizes utility for Singer to publicly acknowledge this "dualism." Those less inclined to favor international relief of poverty may score public points against Singer's views-real, or for public consumption-by pointing out just this duality. Of course, it is possible that Singer has still actually never told us his deepest moral beliefs about the morally ideal level of international poverty relief, and is in this sense still esoterically utilizing his dualism at this level. At some point, all this multi-layered utilitarian strategizing of course becomes dysfunctional from a utilitarian standpoint. See John Gray, Indirect Utility and Fundamental Rights 73; Allan Gibbard, Utilitarianism and Human Rights 92; and James Fishkin, Comment on Gibbard 103 in Ellen Frankel Paul, Jeffrey Paul \& Fred D. Miller, eds, Human Rights (Basil Blackwell, 1984) (attempting to sort out the nature or varieties of, and the attractions and deficiencies of, indirect utilitarianism, of which Singer's approach would constitute one variant). 
in which we impose prison terms for actions we believe are morally permissible, if not morally right. Realistically, we will either gradually cease to impose such sentences or we will reconceive or reweight the various interests at stake, including long-term indirect interests, and then judge some such killings to be morally wrong. Roughly the same analysis applies if we pursue instead the distinction between critical morality, at which some infanticides and child killings would be morally permissible if not morally required, and intuitive morality, at which only early infanticides could be morally permissible, and a flat moral prohibition might be imposed on all others.

Singer's recourse to these two-level analyses seems theoretically unobjectionable. It resembles the standard move in which a utilitarian publicly endorses a flat "rule" against killing innocent adults, on the grounds that allowing persons to try to accurately recognize the rare genuine exceptions to such a rule will lead to worse consequences overall than the otherwise "second-best" approach of uniformly following such a "rule." Such a recommendation is still consistent utilitarianism, guided at every turn by a concern for optimal net consequences.

But to say that the killing of a particular one or two year old is right at the level of critical morality and wrong at the level of intuitive morality may in practice again put too much pressure on the distinction between the two levels of morality. When Singer invokes "intuitive" morality, doubtless he does so on utilitarian grounds, in some principled way, and we may assume that his choice of the particular "intuitive" rule is similarly sound. Surely the "critical" permissibility of a broader range of child killings could not be kept hidden and esoteric, known only to the cognoscenti. If there is a sense in which a particular child killing was really the morally right course, the criminally accused, or the morally impugned, will learn of that sense, and wish to emphasize it heavily.

In all likelihood, the long-term vitality of a more restrictive "intuitive" rule against killing would depend, illicitly from a utilitarian standpoint, on the residual authority of a lingering cultural sense that some killings may be morally wrong for non-utilitarian reasons. It is at such points that Michael Perry's insistence on human dignity, intrinsic worth, and universal fraternity comes into play. The 
stable authority, in practice, of more restrictive "intuitive" moral rules would, however unintentionally, thus implicitly trade on our continuing sense that some killings are morally wrong on traditional theories of the sort championed by Perry.

Singer himself considers a general historical prohibition on infanticide to be rather narrowly religiously derived, ${ }^{93}$ and notes that it is characteristic of only some societies, and not others. ${ }^{94}$ Actually, it is difficult to know whether the standard prohibition on infanticide is a direct reflection of particular religious doctrines. Anyone can worry about any slippery slope, or about gradual desensitization, and it may also be that infanticide is less characteristic of relatively wealthy societies. A wealthy society in this sense could be any society that has developed an economic surplus such that a family's basic well-being is not jeopardized by a child who is severely disabled, or who seems likely to be a long term economic liability.

More broadly, there is perhaps even a lurking motivational tension between what Singer finds morally permissible in this context, and what he sees as the morally proper treatment of disabled adult jobseekers. This problem, again, is not directly one of logical inconsistency. Instead, it is mainly a matter of what it is realistic to expect, over the long term, of ordinary persons. The problem is, as Michael Perry recognizes, one of motivation and consistency. Singer believes that we should see the killing of disabled infants, in appropriate instances, as a morally permissible or good thing. Singer also believes, as we have seen, in some degree of societal sacrifice in favor of disabled adult jobseekers and disabled employees. ${ }^{95}$ It is certainly possible to consistently hold both of these views. That it is possible to do so without contradiction, however, does not show that most people, over the long term, will find it psychologically practical or attractive to do so. Adults with disabilities lack the advantages, on Singer's account, of diminutive size, cuteness, and the ability to evoke protectiveness. Certainly, disabled adults will on the other hand have interests and capacities not held by infants. ${ }^{96}$ But it is already difficult enough, as Michael Perry recognizes, to persuade

93. Id at $\mathbf{1 7 2 .}$

94. Id.

95. Id at 52-53.

96. Id at 171 . 
people of the justice of substantial sacrifice in favor of an adult stranger who is disabled. It may eventually prove even more difficult to motivate such sacrifice in favor of persons whose disabilities once counted to some degree in favor of their death, for the sake of the interests of others.

Let us then turn to briefly consider the distinctive moral issues raised by Quasimodo not as child, but as an adult. Again, Singer would want at a minimum to reasonably accommodate Quasimodo in his capacity as bellringer. ${ }^{97}$ It is far from clear, however, that Singer's utilitarianism can even protect the adult Quasimodo from the barbaric depredations of the Parisian establishment and the Paris mob. It is certainly possible for Singer to argue that allowing Quasimodo's mocking, misunderstood investiture as the "Pope of Fools" and his later pillorying cater to the absurd religious superstitions of the mob and to their revulsion at his appearance. Singer can then point out that it is in the long-term real interests of the masses that their superstitions be denounced and extirpated, rather than catered to. The masses generally think Quasimodo demonic, ${ }^{98}$ wicked, ${ }^{99}$ a consort of witches, ${ }^{100}$ and a caster of spells. ${ }^{101}$

97. Actually, Quasimodo would have had as much interest in OSHA protection as in the ADA. The combination of his congenital disabilities and a "workplace accident" resulting in a further disability had a multiplicative adverse effect on his psyche and status. Victor Hugo's account is as follows:

Bellringer of Notre-Dame at fourteen, yet a new infirmity came to complete his apartness. The bells had broken his tympanum, so he had become deaf. The only door that nature had left open wide to the world had suddenly been closed forever.

And its closing cut off the only ray of joy and light that had penetrated to the soul of Quasimodo. That soul was plunged into profound darkness. The wretch's melancholy became incurable and as complete as his deformity. Besides, his deafness rendered him in some way dumb. For, in order that he might not be laughed at, from the moment he knew he was deaf, he resolutely determined to keep silent.

Hugo, Hunchback at 154 (cited in note 70). Query whether a utilitarian should take this sort of constant melancholy into consideration when making moral decisions affecting Quasimodo. Does the politically regressive character of some of the causes of Quasimodo's melancholy bar its being considered?

98. Id at 52 .

99. Id. 
This sort of thinking, however intensely felt, does not herald the acme of human fulfillment.

Singer is thus certainly entitled to recognize the indirect, longterm costs of catering to ignorance and superstition, and the corresponding benefits of promoting enlightenment. But none of this necessarily carries the day on a utilitarian calculus. It would be an odd sort of utilitarianism that absolutized enlightenment over the indulgence of mass superstition and vulgar, if intense and widely shared, prejudice, either at the level of general moral principle or of particular decisions. Utilitarianism is not, and does not guarantee, perfectionism. Neither does it invariably validate the sort of universal fraternity endorsed by Perry. The public authorities wish Quasimodo to be pilloried. The crowd's reaction, at the pillorying and when they mockingly name Quasimodo as "Pope of Fools" in a way he mistakenly enjoys, ranges from intense visceral hostility, to fear, to contempt, to amusement at his plight. ${ }^{102}$ Consider, for example, the moment in which

Quasimodo again looked at the crowd despairingly, and repeated in a tone yet more heartrending, "Some water!"

But again everybody laughed ....

A woman threw a stone at Quasimodo's head. "This will teach you to wake us at night with your cursed ringing!"

These sentiments admittedly are not - universally shared. Esmeralda in particular is moved with pity, ${ }^{104}$ though even after her

100. Id at 53.

101. Id.

102. Id at 229-31. For the mocking investiture of Quasimodo, affording the best of all direct utilitarian worlds, in which both the crowd and Quasimodo are delighted with the proceedings, see id at $51-54,69-70$. See especially id at 65 ("It is difficult to give an idea of how much pride and beatific satisfaction registered on the usually sad and always hideous visage of Quasimodo as he rode. It was the first moment of self-love he had ever enjoyed.... He took seriously all the ironical applause, all the mock respect ....”). Query whether the moral wrongness of this abuse of a deformed or disabled person should depend on, for example, whether Quasimodo eventually realizes the true nature of the proceedings, and is then embarrassed or angry. Of course, some deduction on utilitarian grounds must be made for any adverse consequences flowing from anyone's being led by this incident to mock or deceive, successfully or not, other persons.

103. Id at 231. 
own rescue by Quasimodo, she cannot overcome her feelings of repugnance at Quasimodo's appearance. ${ }^{105}$ Certainly, Quasimodo's sentiments can be weighed in the utilitarian balance against his own pillorying, though probably not against his mock investiture. If any device ever suggested our applying a hedonic calculus, it is certainly the lash. But even on this dimension, the long familiar public response to his disabilities and appearance has, perversely, tended to undermine the severity of some of the pillorying's effects on Quasimodo. His reaction is, to his credit, initially one of incomprehension, and his ultimate reaction still lacks some of the dimensions we might have expected: "On his face there was neither shame nor blush. He was too far from the state of society and too near the state of nature ${ }^{106}$ to know what shame was." 107 His Rousseauian noble savagery thus disserves him on the utilitarian calculus.

The utilitarian thus cannot simply pronounce Quasimodo's pillorying a sadistic travesty. Quasimodo is used to public contempt, though certainly not to physically painful abuse, and it is not surprising when persons in such circumstances develop a kind of psychic carapace to minimize all but the most elementally physical shocks. Nor does the pillorying substantially undercut what are called, however crudely, Quasimodo's central life projects, ${ }^{108}$ or his central life interests, beyond the pain and the brute physical dimensions of the flogging itself. Quasimodo's interests, desires, and preferences cannot simply be automatically elevated above those of the mob. They must, however central one or more of them may be to Quasimodo, rest in the balance against those of a mob whose grievances against Quasimodo are in some cases quite basic, longstanding, and intense (however fearful, intrusive, superstitious, or otherwise misguided).

Singer thus cannot say, with even a modest degree of assuredness, that the papal investiture or even the pillorying of

104. Hugo, Hunchback at 232 (cited in note 70).

105. Id at 368 .

106. Jean Jacques Rousseau, Discourse on the Origin of Inequality 175 (Oxford U Press, 1950).

107. Hugo, Hunchback at 229 (cited in note 70).

108. See notes 110-15. 
Quasimodo failed to maximize the preference satisfaction of all affected parties. Instead, the utilitarian logic of Singer's position forces him to inquire, somewhat disturbingly, into matters such as the sheer size of the mob, its intensity, its shifting moods, and more speculatively, whether Parisians over some arbitrary time frame might be capable of disposing of some of their crudely oppressive superstitions along with, eventually, their similarly oppressive ruling elites. In contrast, it is open to Michael Perry to more directly reach the right result in this case by an immediate appeal, for example, to human dignity.

These sorts of problems, however, do not exhaust those that Singer must face. They are not even the most interesting such problems. Contemporary disability activists and theorists have argued that the value of the lives and projects of many disabled persons tends to be opaque to the nondisabled. ${ }^{109}$ At its most blunt, direct, and potentially threatening, the question ignorantly posed by the non-disabled is one of how the disabled can 'live like that.' In part, addressing this occasionally life-and-death problem is a matter of gradually enlightening non-disabled persons to unexpected sorts of value. With the task of enlightening the beknighted, the utilitarian can readily manage. But the problem goes deeper. There may as well be value in the life and "life projects" of a disabled person that is unlikely to be recognized, let alone somehow properly weighed and assessed, by the utilitarian decisionmaker. There can even be positive value in the failure or "frustration" of one's projects. This adds to the arbitrariness, misguidedness, and indeterminacy, of Singer's logic and outcomes.

We can, as potential moral decisionmakers, admittedly see value in Quasimodo's heroic rescue of Esmeralda. ${ }^{110}$ Even the crowd sees some sort of value in Quasimodo's act, and in Quasimodo himself, at least at that moment." ${ }^{11}$ Quasimodo is at this point not

109. Shapiro, No Pity 4, 14, 85, 282 (cited in note 72).

110. Hugo, Hunchback at 347-48 (cited in note 70).

111. Id at 347. ("The women laughed and wept; the crowd stamped their feet enthusiastically, for at that moment Quasimodo was really beautiful. $\mathrm{He}$ was handsome-this orphan, this foundling, this outcast. He felt himself august and strong"). 
oblivious to his own heroism. ${ }^{112}$ Trying to place some sort of determinate moral value on this, or on Quasimodo's humble and largely unrequited devotion to Esmeralda, ${ }^{113}$ lead the utilitarian into arbitrariness. But at least we are here aware of, and have words to characterize, the presence of morally relevant value.

Are moral decisionmakers, on the other hand, likely to recognize, let alone somehow properly assess, the value of Quasimodo's sheer physicality, and the inarticulable dimensions of his sensuous, deeply social, and conceivably even spiritual relationship with the bells and gargoyles, ropes and passages, of Notre Dame? This is an essentially private world, largely unobservable and uncognizable by the outsider.

How does the utilitarian recognize and weigh the possibility of sublimity? What coefficient, roughly, is to be given to the ineffable? Perry's general approach is sounder here. Perhaps there is even some risk that a society's thinking in utilitarian terms will lead to increasing insensitivity toward, if it does not actually undermine, such value. Can the utilitarian simply say that reactionary, barbarous Notre Dame is clearly part of the problem, that Notre Dame and what it stands for oppress and disable Quasimodo, so that the positive and negative utility terms neatly cancel one another? This would be an astonishing coincidence. Can the utilitarian say that whenever the utilitarian calculus strikes us as especially hazy or suspect, we should then drop down to some unspecified "intuitive" moral rule? Consider a portion of Victor Hugo's description:

the cathedral did seem like a creature, docile and obedient in his hands. She waited upon his will to lift up her loud voice; she was possessed by him; she was filled with Quasimodo, as with some familiar spirit. You would have said that he made this immense structure breathe. ${ }^{114}$

Hugo concludes: "Egypt would have taken him for the god of this temple; the Middle Ages believed him to be its demon. But he was in fact its soul."115 Translating any of this into utilitarian terms with any fidelity seems almost unimaginable. Even at the very least,

112. Id at 347-48.

113. Id at 368 .

114. Id at 154 .

115. Hugo at 154 (cited in note 70 ). 
the utilitarian is forced not merely to count, but to radically choose among utterly distinct general understandings of value.

Our dim recognition of these elements of Quasimodo's life suggests that Quasimodo and his "projects" are neither graspable nor replaceable values. It would even be misleading to say that Quasimodo is of infinite value, as this might hold open the possibility of quantitatively comparing Quasimodo's life with that of some other commensurately infinitely valuable person. Quasimodo's life is perhaps better thought of as irreplaceable, even if he were to be killed and in a crude sense "replaced" by another bellringer. ${ }^{116}$ Quasimodo is in this sense morally incommensurable, as are the rest of us, even if we can be reasonably called upon; tragically, to sacrifice our lives, and even if we do not live our lives with the same sublimity as Quasimodo's. Quasimodo's life is obviously more sequestered than ours, but in a deeper sense, the nature of each of our lives is not fully publicly accessible. Our incommensurable "value" in this sense is really no more empirically observable, and no more articulable by ourselves or by others, than is Quasimodo's. Again, the contrasting approach of Michael Perry reaches the right results with immediacy. As soon as we recognize that Quasimodo is our neighbor, we know there are certain things we must not do to him.

In sum, we cannot realistically hope to grasp and meaningfully assign even some rough "value" 117 to the life of a disabled person. If this means that we must therefore posit occult, mysterious entities such as incommensurable value, despite our occasional willingness to sacrifice one to save many, that is where our experiences have inescapably led us. Let us note, though, that Singer himself chooses to rely on arguments of a different, but in a sense equally occult status. Consider the ultimate mysteriousness of how Singer seeks to transcend the relatively simple moral world of real pains and pleasures:

an action contrary to the preference of any being is, unless this preference is outweighed by contrary preferences, wrong. Killing a person who prefers to continue living is therefore wrong, other things being equal. That the victims are not around after the act to lament the fact that their preferences have been

116. Singer, Practical Ethics at 186 (cited in note 42):

117. This would encompass both cardinal and ordinal or ranking values. 
disregarded is irrelevant. The wrong is done when the preference is thwarted. ${ }^{118}$

This seems familiar enough, but on reflection, it is actually too exotic to remain within the bounds of any standard utilitarianism. Certainly, a utilitarian can take into consideration the various indirect post-mortem effects of killing a person who is, let us say, asleep, heavily sedated, or in a deep, prolonged coma. But to go much beyond this is to press beyond the limits of any familiar sort of utilitarianism. Calling it 'preference utilitarianism' does not by itself explain or motivate an inclusive focus on preferences unrelated to any kind of pleasure or pain.

There is an obvious utilitarian difference between a prolonged, dreaded, agonizing death, and a painless, unanticipated death, by foul play or otherwise, during sleep. There is also a utilitarian difference between the conscious frustration of our desires, when we know they are being thwarted, and the never-conscious "frustration" of our desires, in the sense of an extinction and non-fulfillment of desires, where we do not anticipate or experience that extinction or nonfulfillment. It is far from clear how Singer can cogently treat these situations similarly. To do so is to attach utilitarian moral weight to utterly unexperienced events as though we had experienced them. For a utilitarian to rely on what is not experienced, perhaps even in the permanent absence of an experiencing subject, is mysterious. Doubtless there are all sorts of sound indirect utilitarian reasons for keeping deathbed promises, carrying out the wills of the deceased, and such. But Singer clearly wants to go beyond this.

Let us suppose that I have a desire that simply evaporates and loses its motive force, without being fulfilled or replaced. I merely note the passing of my desire, without emotion. This desire, while certainly not frustrated, is also not fulfilled. Is this also a bad thing from Singer's standpoint? Why isn't it perhaps a good thing, along Stoic, Buddhist, or Thoreauvian lines? What if another person strongly desires to extinguish, in just this way, my weaker desire, and does so? Isn't this a good thing from a utilitarian standpoint, all else-including indirect consequence-equal? What if that intervener extinguishes the desire in one person's mind but

118. Id at 94. 
simultaneously transplants it to various other minds, ${ }^{119}$ without conflict?

Singer speaks of the idea of 'violation,' and of making "nonsense of everything that the victim has been trying to do" 120 in the case of the killing of unconscious persons. We have seen reason to wonder whether this really makes sense from a utilitarian standpoint. There is certainly a sense in which our long-term desires do not cease when we are unconscious. ${ }^{121}$ But why should a desire that is not now felt, and never again will be felt, directly count? Ultimately, the logic of violation or of making nonsense of the lives of unconscious homicide victims is really not entirely utilitarian. Rather, these ideas take much of their force from, and have their home in, non-utilitarian understandings of human dignity. Michael Perry can, in contrast to Singer, appeal directly to the ideas of violation, and of undermining the meaning of a person's life, even where the victim does not consciously experience or recognize such violation. This flows from any reasonable elaboration of the idea of human dignity.

Singer's utilitarianism really cannot satisfactorily explain the right moral outcomes in such unconscious homicide victim cases. It may not even provide the morally right outcomes. At best, Singer's approach is unnecessarily indeterminate. What if, however unattractively, we are forced to choose between killing A and killing the generally similar B, where A has made a firm and successful long-term commitment to his own intense sensory gratification, whereas B has recently lost his faith in a similar lifestyle, but has not yet formed any serious replacement projects or basic commitments? Singer seems committed, all else equal, to the view that it is actually

119. For a particularly exotic set of possibilities, designed to resolve some deep and challenging problems in the interpretation of quantum mechanics, see, for example, David Z. Albert, Quantum Mechanics and Experience 130 (Harv U Press, 1992); Michael Lockwood, Many Minds Interpretations of Quantum Mechanics 47 Brit J Phil Sci 159 (1996); David Papineau, Many Minds Are No Worse Than One 47 Brit J Phil Sci 233 (1996). For brief speculation on some possible moral and legal consequences of related ideas, see R. George Wright, Should the Law Reflect the World?: Lessons For the Law from Quantum Mechanics 18 Fla St U L Rev 855 (1991).

120. Singer, Practical Ethics at 95 (cited in note 42).

121. Id at $98-100$. 
worse to kill A rather than B. But this seems doubtful, for reasons most naturally expounded from a non-utilitarian dignitary perspective.

Or suppose the choice is between $\mathrm{A}$ above and $\mathrm{C}$, where $\mathrm{C}$ has, at age 35 , just achieved the admirable goal to which she has singlemindedly devoted all of her thoughts and efforts for the past two decades. Indirect effects again held constant, should we say, as Singer seems committed to, that it is better to kill C than A? After all, A has his ongoing "central" projects and commitments, whereas $\mathrm{C}$ does not. But again, this seems doubtful, at least if we set aside the indirect incentive effects.

A deeper challenge to Singer, however, is that of the ultimate meaninglessness and sheer arbitrariness, from a rational standpoint, of acting in accordance with Singer's thin metaethics and utilitarian standards. Here, the approach taken by Michael Perry offers real advantages. Problems of ultimate meaninglessness and of arbitrariness loom large for Singer, as he rejects any "mysterious realm of objective ethical facts." 122 He wishes us, nonetheless, to adopt a universalist approach, in which we equally consider the interests of all affected parties along with our own. He recognizes the possibility of a selfish devotion to one's own narrow personal interests, ${ }^{123}$ and rightly concludes that such a narrowly focused life will typically not be particularly meaningful. ${ }^{124}$ Of course, a society may find continued adherence to a now non-objective morality to be meaningful in some sense, at least for a time, just as a person might find meaning in an arbitrary devotion to the Hatfield clan. However, as Perry recognizes, this does not really resolve the problem of moral meaningfulness, or show the moral life to any rational advantage in this respect.

122. Id at 8. Out of an abundance of caution, we might emphasize that Singer is here rejecting moral objectivity in general, not just some particularly mysterious version thereof.

123. Id at 317.

124. Id at 332. For discussion of the familiar idea of the ultimate unsatisfactoriness of a devotion to consumption of goods and services, see R. George Wright, Selling Words ch 1 (NYU Press, 1997). Classically, see, for example, The Bhagavad-Gita 134 (Columbia U Press, Barbara Stoler Miller, Trans, 1986) ("In their certainty that life consists in sating their desires, they suffer immeasurable anxiety that ends only with death."). 
The basic problem Singer must face, given his rejection of objective morality, is to show first that the morally lived utilitarian life is genuinely meaningful in a socially stable way and not ultimately arbitrary from a rational standpoint, and second that lives that do not aspire to utilitarian or other universalist morality, but are also not narrowly self-absorbed, are somehow less meaningful than Singer's own moral schema. This is, in effect, the challenge posed by Perry. To simplify Singer's task, we shall join him in assuming that the life of self-absorption is likely to be unappealing over the long term. Actually, it may well be that with future technological advances of various sorts, the life of self-indulgence and selfgratification will come to be, if not meaningful, much more efficient and at least thoroughly preferred by those who can afford it. This prospect should give Singer pause. Singer deserves great credit for not simply dismissing the problem of ultimate meaninglessness. But it cannot be said that his analysis is reassuring.

On Singer's view, moral principles are not rationally binding, or somehow authoritative for us, or a reflection of some sort of order of nature or the universe. The universe itself is presumably meaningless. There is no objective morality, and it is not objectively right to aim to act in accordance with any moral scheme. Whatever we do to Quasimodo may be approved by a large group, but cannot possibly be "really" right or wrong. Morality is in this sense gratuitous. Michael Perry recognizes the realistic implications of this view. If it pays us to ignore, or to merely pretend to adhere to, some moral scheme, it is not "really" wrong to do so. There is, as Perry argues in particular, not much reason to accommodate the interests of the weak, of the poor, of other species, of those with congenital disabilities, ${ }^{125}$ or in general of those not likely to be in a position to reward or punish us. Sacrifice on behalf of strangers, and those who cannot benefit us in return, is as Perry recognizes especially curious, in addition to being ultimately arbitrary. It may be a popular or

125. We would expect the congenitally disabled, and in particular the severely congenitally disabled, to lose by the absence of any binding, authoritative moral rule requiring assistance or compensation. On the other hand, those disabilities to which the rest of us may as adults yet become vulnerable, such as back problems affecting one's ability to work, might under such circumstances be better accommodated. 
amusing public pose, at least for a time. Particularly for those who are moderately well off, and who have resources that might well benefit those far less well off, this pose may eventually lose its appeal. We are in the long run probably better off catering to, or insisting on equality with, those who are close or powerful enough to threaten or reward us in some way. In a meaningless universe, we cannot simply construct a stable moral meaningfulness from scratch.

Of course, we can invest any object or pursuit with a certain gratuitous significance merely by choosing, however arbitrarily, to care about it intensely and prolongedly. ${ }^{126}$ In this fragile sense, nonobjective morality can, along with joining even a completely fungible, non-service oriented fraternity or rooting for a sports team, confer meaning. The problem for Singer then becomes one of showing how, in this sense of meaningfulness, the moral life is likely to be more meaningful than lives that do not aim at equal and universal concern for others, but that also avoid unduly narrow and ultimately unsatisfying self-absorption. It is, as Perry argues, quite common to create this sort of meaningfulness through caring about some other persons, while falling far short of Singer's broad moral concern. ${ }^{127}$ The range of one's concern may be limited to a favorite species, class, country, partisan cause, clan, family, or to some other limited grouping no more objectively meritorious than another. Meaningfulness therein derives from identifying with and helping limited groups, reviling and battling selected antagonists, and manifesting indifference or feigned, at best trivial benevolence to most others. This sort of life can easily be, unfortunately, at least as

126. Singer recognizes, for example, the possibility of devoting oneself to postage stamp collecting. Singer, Practical Ethics at 334 (cited in note 42).

127. For one reaction by Singer to the problem of focused concern on one's close relatives and the evolutionary precariousness of broader concerns, see id at 243. As well, it would at least raise a question for Singer to reduce morality to something like mere preference satisfaction, but to then adopt an understanding of the meaningfulness or significance of life that transcends this standard. If there were more to the meaningfulness of life than some sort of preference satisfaction, we might, perhaps, want to reflect that in our moral scheme. For discussion of the moral point of view in general, see, for example, Kurt Baier, The Moral Point of View (Cornell U Press, 1965); Bernard Gert, Morality: A New Justification of the Moral Rules (Oxford U Press, 1988). 
emotionally meaningful as anything Singer's broad, moral focus can offer.

Since it is not objectively authoritative or rationally binding, and may well not maximize one's long-term gratification, particularly if one is well off, why bother to adopt the impartial moral point of view? Why really sacrifice for the wretched of the earth, unless one thereby somehow scores points? Singer does not pretend to offer a universally cogent answer to Perry's questions in this regard, or to address the circumstances of the well off in particular in this context. He does offer two general considerations. First, there are some fascinations, unlike a commitment to the broad, moral point of view that many of us grow out of. Singer notes that some persons "find collecting stamps an entirely adequate way of giving purpose to their lives. There is nothing irrational about that; but others grow out of stamp collecting ... To this group the ethical point of view offers a meaning and purpose in life that one does not grow out of."128

Most of us, still along with many moral philosophers, do not yet think of morality as a matter of collective juvenalia out of which we eventually mature. But there is, on Singers's own analysis, no reason not to think of morality in roughly this way. Again, morality lacks any objective cogency. Why not view morality as a delusion, whether genuinely useful or not, or as the revenge of the weak, or as a collective con game or a device for repressing disfavored particular groups? Any number of schools of thought have come to reject all moral thinking as Singer understands it. ${ }^{129}$ Such philosophers, and other academics, could easily conclude that they have intellectually and emotionally outgrown moral thinking. Some might recommend that the rest of us follow suit; others might not. A number of narrower, non-moral commitments may thus be no less stable than a commitment to non-objective morality.

Singer's second attempt to show that morality offers greater meaningfulness than non-moral group commitments is a bit more abstract. He argues that "looking at things ethically is a way of ... identifying ourselves with the most objective point of view

128. Singer, Practical Ethics at 334 (cited in note 42).

129. John L. Mackie, Ethics: Inventing Right and Wrong (Penguin, 1977); Richard Garner, Beyond Morality (Temple U Press, 1994). 
possible - with ... 'the point of view of the universe."'130 This is, however, a curious argument for Singer to make. Singer here adopts the literal terminology of Michael Perry's argument, but not its substance. 'Objective,' as Singer here uses the term, can mean only something like 'broadsweeping' or 'encompassing,' as opposed to focused or relatively narrow. Surely it is either mistaken or merely question begging for Singer to suppose here that the noncognitivist moral point of view is "really" the best perspective to adopt from the standpoint of rationality.

This is partly a matter of the connotations of verbal labels. In our culture, at least, a "broad" point of view seems associated with inclusiveness and non-discrimination, and a "narrow" point of view with less appealing qualities. But these associations of 'broad' and 'narrow' have their appeal only within an assumed moral context. It is better to be socially inclusive than non-inclusive. But this is so only once we have already adopted the moral perspective, and whether we should rationally do this is precisely what is at issue. Of course, it might also be better, in a non-moral way, to choose a way of living based on broader considerations rather than narrower consideration, at least up to a point. But thinking about a relatively broad range of considerations, in Singer's world, does not lead us to endorse a moral as opposed to a merely group-based approach to living. Particular groups differ in their own breadth or inclusiveness as well.

Perhaps we could avoid this error if, instead of asking whether a broad perspective is better than a somewhat narrower perspective, we asked whether a diffuse, barely comprehending perspective is really better, or more meaningful, than a somewhat more focused, more comprehending perspective. By way of loose analogy, we might ask whether it is really more meaningful to be a competent general practitioner than a competent heart surgeon. It is also true that narrowing the scope of those with whom we identify or

130. Singer, Practical Ethics at 334 (cited in note 42). For an argument loosely akin to that of Singer, see Jenny Teichman, Humanism and the Meaning of Life 6 Ratio 155, 162 (1993). For some doubts see, for example, Garth L. Hallett, Greater Good: The Case For Proportionalism 31 (Georgetown U Press, 1995); Robert Kane, The Ends of Metaphysics 33 Intl Phil Q 413, 427 (1993) and, to some degree, Charles Larmore, The Right and the Good 20 Philosophia 15, 30 (1990). 
empathize - say to humans alone-does not preclude a non-moral, but meaning-conferring interest in rotifers, viruses, trees, penguins, Klingons, angels, and unicorns.

Doubtless there does seem something bracing about adopting, or at least attempting, however ineptly, to adopt something called the point of view of the universe. For some-perhaps most-this may eventually turn out, however, a bit abstract, diluted, cold, and unmotivating. After all, on Singer's own analysis, as opposed to Michael Perry's, the universe does not really have a point of view. In itself, the universe is mute and meaningless and quite possibly destined to eventually go unceremoniously out of business. The universe does not want us to adopt any particular point of view, let alone its own nonexistent point of view. Why would adopting a more general point of view then be more meaningful than some set of loyalties, non-moral in Singer's sense, that transcend assumedly selfdefeating egoism? Michael Perry, in contrast, holds open the possibility of a universe that can be seen as hospitable.

Let us try, then, to do a final accounting of Quasimodo's fate under alternative regimes. What sorts of conclusions can be drawn if we try to compare Quasimodo's life under even the especially bizarre, grotesquely distorted if officially sanctioned historical moral objectivism of Notre Dame, under Singer's version of utilitarianism applied to those circumstances and events, and under Michael Perry's understanding of human rights? No doubt Singer would much prefer to start from scratch, on a more congenial utilitarian cultural basis, without the superstitions and oppressive dogmas of the historic Notre Dame, at least insofar as they failed to maximize utility. It can still, however, be illuminating to apply utilitarian percepts to historical circumstances largely untouched by a utilitarian culture. Doubtless utilitarianism should want to strive for such breadth of applicability.

Singer can again offer Quasimodo, in his capacity as bellringer, something like OSHA and the Americans with Disabilities Act. Perhaps further training, reasonable accommodations, and job promotion should be available. At a minimum, something like modern headphones to prevent deafness should have been provided. This assumes, of course, that Quasimodo makes it to adulthood on a utilitarian calculus. In contrast, the historic Notre Dame offered limited developmental assistance, for which Quasimodo was 
immensely grateful, and much risk to life and limb. As well, Notre Dame was at the very least complicitous, if not clearly a leading element, in much of the underlying oppressive cultural hostility to Quasimodo, and in his consequent suffering. The inescapably crucial and unresolvable question, however, is whether Notre Dame can also offer Quasimodo utter, if inarticulable, sublimity, of a sort unencompassed within a utilitarianism without moral objectivity or a meaningful universe. ${ }^{131}$

The mob's investiture of a deludedly delighted Quasimodo as "Pope of Fools," and even the later pillorying of Quasimodo, pose difficulties and uncertainties for Singer that are greater than we should feel comfortable with. Singer, by his own logic, should in such cases ask questions about the size of the mob, its fervor, its constancy, the centrality of the relevant beliefs, the selfdestructiveness of those beliefs, the mob's gradual educability, and about Quasimodo's expectations, prior state of mind, pain threshold, and so forth. There seems great and unnecessary indeterminacy here. Singer may arrive eventually at what we would take to be the obvious right answer in such cases. He may even wish on some principled utilitarian grounds to short-circuit the calculations by developing an "intuitive level" moral rule about, for example, abusively creating deluded joy in persons unable to recognize that the "honor"

131. It is worth noting that Quasimodo's case challenges many mainstream accounts of the value of lives. Consider, for example, Philip Kitcher's argument:

When we try to evaluate the quality of a human life, we should attend to three different dimensions. The first focuses on whether the person has developed any sense of what is significant and how the conception of what matters was formed. The second assesses the extent to which those desires that are central to the person's life plan are satisfied: did the person achieve those things that mattered most? Finally, the third is concerned with the character of the person's experience, the balance of pleasure and pain.

Philip Kitcher, The Lives to Come: the Genetic Revolution and Human Possibilities 289 (Simon \& Schuster, 1997). This does not bode well for Quasimodo as a young child, and seems, in several respects, insensitive and unresponsive to Quasimodo's life as an adult. Quasimodo's life is not focused on freely developing and then fulfilling a life-plan in a conscious or literal sense. Few persons seem less free, or to have less freely chosen. His balance of pleasure over pain seems, as far as public moral decisionmakers can tell, abysmal. 
apparently being accorded is only mockery. But much of this "intuitive" rule construction seems slightly off the track, or else an ad hoc attempt to accommodate our intuitions that utilitarianism does in fact take us off the track. ${ }^{132}$ Our intuitions in this regard are more likely to track Michael Perry's sense that contempt and hatred are the inversion of the moral. They represent, on Perry's understanding, withering rather than human flourishing, if any further argument against them is necessary.

To deny moral objectivity is to deny that, in some here unspecified but familiar sense, what the mob does to Quasimodo is morally wrong, not just on some broad moral scheme we have contrived, representing our best constructive efforts, but somehow really wrong. Perry recognizes that Quasimodo's status as neighbor is not simply a matter of moral bootstrapping. As Jean Hampton expressed this sense,

Outside of our philosophical study... we don't think we're merely "expressing our acceptance" of norms calling for mutual respect and social justice when we make (sometimes great) personal sacrifices in order to comply with these norms. We act as if we think the authority of these norms is not "in our heads" or traceable only to social conventions and our (cognitive or affective) reactions to them, but "real". ... .

Doubtless there are many kinds of cases in which morality does not require the sacrifice of even narrow self-interest. Often, acting morally, on any reasonable theory, will seem agreeable. But ultimately, as Perry argues, it is substantial sacrifice from us and those who are close to us, in favor of those who cannot threaten or repay us or our own group, for which Singer cannot offer cogent, stable, non-arbitrary motivational reasons. ${ }^{134}$ Objectivity of morality

132. A complication, however, lies in the possibility that the arguable sublimity of Quasimodo's life in Notre Dame is in one or more respects causally dependent on the public's absurd fear, contempt, and revulsion toward Quasimodo.

133. Jean E. Hampton, in Richard Healey, ed, The Authority of Reason 120 (Cambridge U Press, 1998). For further general discussion, see Nicholas Rescher, Objectivity: The Obligations of Impersonal Reason chs 9-10 (UND Press, 1997).

134. Consider a case in which a modern day Quasimodo comes to slightly prefer working, for a time, at a small family owned restaurant-in the unenlightened section of town-to continuing his vocation as bellringer. Let us assume that some patrons will react negatively to the fully qualified Quasimodo, based on sheer 
is, despite the sordid history of abuse that Perry fully recognizes along with its shining moments, the best hope of the outcast and the oppressed. It is precisely the outcast and the oppressed, who lack the ability to bargain or threaten credibly, who have the clearest stake in objective morality.

Singer's abandonment of moral objectivity thus unintentionally undermines the interests of the powerless, the outcast, and the oppressed. If Singer offered any cogent reason for supposing moral objectivity to be a delusion, this result might be sound and inevitable, however unfortunate and unattractive. He does not offer any such cogent reason, however, so any additional suffering imposed on the powerless by the abandonment of moral objectivity seems itself gratuitous. Certainly, Michael Perry does not attempt to establish the existence or binding validity of any set of human rights. But as we have seen, there is much to be said even if neither Perry nor Singer seeks to prove the validity or invalidity of any objective human rights claims.

If it were the case that Singer's version of utilitarianism offered the powerless and the oppressed a clear advantage of some sort, by comparison with rival moral theories, and that such advantage could arise only at the cost of jettisoning moral objectivity, that would be an obviously important result. But Singer's utilitarianism offers no such advantage. Consider again in general how Singer's theory might handle the depredations imposed upon Quasimodo. What strikes us is how curious, how awkward, and how indeterminate, at best, the application and outcome of Singer's theory would be, even if Singer is granted the retreat to "intuitive" moral rules, and to some particular such rule, on some principled basis.

Ultimately, risks to Quasimodo, and to persons with disabilities in general, flow from Singer's understanding, as distinctly opposed to

irrational prejudice, and that as a result, the owners of the restaurant will incur substantial financial losses, if they are able to stay in business at all. Singer's view seems to be that it would be morally wrong for the owners to fail to hire or to dismiss Quasimodo on the indicated grounds. See Singer, Practical Ethics at 52 (cited in note 42). Our question is not whether Singer is right about this. Instead, it is whether Singer can offer any cogent account to the restaurant owners of what Singer would presumably morally require of them, in light of Singer's attenuated metaethics. This hypothetical case, by the way, illustrates the obvious value of some sort of tax or other subsidization program in appropriate cases. 
Perry's, of what a system of ethics really amounts to. Singer's view is that "[e]thics, though not consciously created, is a product of social life that has the function of promoting values common to the members of society. Ethical judgments do this by praising and encouraging actions in accordance with these values."135

Persons with disabilities, along with other historically disfavored groups, face two related problems on Singer's understanding of the nature and function of ethics. First, while selffulfillment may, in various senses, be a common value, there may also be no common value of providing the means to self-fulfillment to congenitally disabled persons, at any substantial cost to the rest of society. At this level, there may be conflict, as opposed to commonality, of interest and value. No doubt congenitally disabled persons can appeal to certain generally formulated common values in an attempt to advance their cause. So, however, can comfortably well off non-disabled persons who would prefer not to part with their privileges and resources. Redressing undeserved disadvantage is not yet a genuinely common value.

We might, as a society, have a genuine common value of trying jointly to create more common values, and to strengthen those common values. Such a value would, however, not tell us much about how, concretely, to address the moral claims of disabled persons. Nor does it seem likely that such a common value would effectively broaden our inclination to sacrifice for the sake of persons with disabilities. We might well imagine that one of the common values of our society is precisely to celebrate diversity and plurality, rather than commonality, of values. Of course, it is also open to question whether any specifiable value is really "common to the members"136 of our own society, in any useful sense.

The second, and related, problem is the vaguely self-defeating character of what Singer takes to be the function of ethics. One way of looking at the problem is to see that if ethics is widely seen as functional, in Singer's sense, it eventually ceases to perform its function particularly well. To the extent that we still see morality as somehow "real," we may see it as rationally binding and

135. Singer, Practical Ethics at 323 (cited in note 42).

136. Id. 
authoritative. To the extent, however, that we see morality as an unconsciously constructed, if perhaps consciously maintained, collective manipulation for the sake of some set of desired outcomes, morality gradually tends to lose its authority and its efficacy. On Michael Perry's approach, in contrast, ultimate meaning is to be discovered. It can be manipulated by the powerful, but there will then be a discoverable gulf between the pretense and the underlying reality.

This is certainly not to suggest that even a consciously collectively manipulative moral system is without power to maintain or change behavior. But there comes to be nothing special about such a system, just as there is nothing special about a Skinnerian ${ }^{137}$ world in which we reinforce some behaviors, or the expression of particular values. Perhaps some of us can find more and better rewards outside the system of "praising and encouraging actions"138 labeled ethics. More likely, we can optimize our rewards by some radically mixed combination of compliance, feigning, and evasion of the system of ethics.

Persons with disabilities are likely to recognize this constructed praise and encouragement system as a reflection not so much of universal fraternity discussed by Perry, but of social power. They will see this ultimately arbitrary construct as at best the rule of "one person, one input" into the design and operation of the moral system. Those with congenital disabilities will appreciate that such a system is unlikely to begin to offer their deliverance from arbitrariness and genuine injustice. They begin life, often, with fewer resources ${ }^{139}$ with which to praise and encourage actions by others that promote their own basic interests. The non-disabled may, in contrast, even find it in their interests to devote some of their own substantial resources to praising and encouraging disabled persons to accept less redistributive outcomes.

In sum, persons with disabilities have substantial reason not to seek the abandonment of traditional, evolving understandings of what

137. Skinner, Beyond Freedom (cited in note 6).

138. Practical Ethics at 323 (cited in note 42).

139. Any number of disabilities, mental and physical, tend to impair one's earning ability as the economy is currently structured. For broad discussion, see Kavka, Disability (cited in note 66). 
human rights amount to, or of moral objectivism more generally. For this reason, they will be much more at home in Michael Perry's worldview than on Peter Singer's. This may be the bottom line, but it is admittedly not yet the last word. We still need, ultimately, to make more progress in understanding and integrating the roles of putative universal rules and more directly consequentialist calculations in human rights discourse and elsewhere.

At the level of normative principle, the significant difference between Singer and Perry is not over the role of universal rules or of absolutism. Both Singer ${ }^{140}$ and Perry ${ }^{141}$ at the very least hold open the possibility of some exceptionless or absolute legal rules in areas of concern to human rights advocates. Singer and Perry are, on the other hand, equally reluctant to endorse uniform, absolute moral rules in these areas. ${ }^{142}$ Perry holds that at the moral level, human rights are exceptionless only in the sense that they apply to and protect everyone. ${ }^{143}$ Such rights are, however, still conditional for Perry, in the sense of being overridable on sufficiently strong moral grounds, beyond their dependence on the general contingencies of history and circumstance. ${ }^{144}$

What mainly drives Perry's human rights conditionalism at the moral level is his sensible unwillingness to sacrifice the basic well-

140. Practical Ethics at 172 (cited in note 42).

141. Perry, Human Rights at 7, 93, 105-06 (cited in note 1). Perry's arguments here essentially parallel those available to Singer.

142. Id at 7, 91, 95. For Singer, see Practical Ethics at ch 1 (cited in note 42). By way of contrast, Alan Gewirth concludes that even in a nightmarish catastrophe avoidance scenario, "[a] mother's right not to be tortured to death by her own son is beyond any compromise. It is absolute." Alan Gewirth, Human Rights: Essays on Justification and Applications 225, 232 (UC Press, 1982). We might at least argue that anyone who could actually thus torture their own mother, in any direct, graphic way, would be unlikely to be the kind of person who in ordinary life would constitute a shining moral example or typically choose well morally.

143. Perry, Human Rights at ch 3 (cited in note 1). For some doubts on this score, see James W. Nickel at 45 (cited in note 81 ). In some contexts, there may be little difference between saying either that a given right is universally held, but is conditional and non-absolute, and saying that the same right is not universally held by all persons. Of course, both Perry and Singer must, and do, offer answers to the question of who or what qualifies as a proper subject or bearer of moral or legal rights of the relevant sort.

144. Id at ch 4. See also Rescher, Objectivity at 164-69 (cited in note 133). 
being of numbers of innocent persons--perhaps their very lives, or what might be thought of as their own moral or human rights-in order to protect some human rights claim of a single individual. The familiar hypothetical example of sacrificing A's human right in order to literally save the world calls for such a response. To refuse to do so seems, as Perry notes, unduly fastidious, evasive, fanatical, or legitimated only by appeal to some publicly unshared theological doctrine. ${ }^{145}$

A person's human rights can, at the moral level, therefore be overridden under appropriately narrow circumstances. In this way, human rights theory can avoid the above hypothetical global moral catastrophe. But in sensibly declining to let the heavens fall, while still taking rights seriously, ${ }^{146}$ we open up a difficult theoretical problem. We see much of the point of even merely prima facie or defeasible moral rights in their power to trump ${ }^{147}$ considerations of utility, popular preference, or "mere" well being. Thus we would not want to sacrifice A's human right merely for the sake of some slight net payoff in overall social utility. Rights are still to be taken seriously; they do not merely supervene on the result of some sort of utility calculus.

Together, these two arguments awkwardly establish both the overridability and the continuing independent force of moral rights. The difficult theoretical problem lies in putting both of these characteristics of moral rights-their overridability or conditionality, and their real independent force-into a common language or, a bit more formally, to put the analyses of all moral rights cases on a common metric. We might say that it is an inherent, built-in limitation of a right that it no longer exists or applies if the consequences of recognizing it in a given case become "too severe." But this is merely a verbal solution. It is tempting to see overriding a right in order to avoid catastrophe, while allowing a right to trump a modest net utility gain, as two remote cases on the same underlying spectrum. As the severity of consequences of upholding a right increase, we doubtless do become less inclined to uphold or

145. Perry at $95,104-05$ (cited in note 1 ).

146. Ronald Dworkin, Taking Rights Seriously ch 7 (Harv U Press, 1977).

147. Id at 11 . 
recognize such a right. But what is the uniform nature or "units" of the underlying spectrum of cases along which we are moving?

The problem is not that there are middle-range cases where many of us will be unsure whether to uphold the moral right or not, or that such difficult middle-range cases may be common. The problem is also really not one of where that controversial middle ground lies. The problem is instead more basic. The middle ground, wherever it lies, seems to involve a collision of incompatible and untranslatable moral analytical paradigms. This is a deeper sort of commensurability problem. It is a matter of incommensurability at a systemic level, rather than at the level of an individual tragic moral choice. We may call this the "golden spike" problem.

Imagine by way of analogy that we have constructed in two segments a system to transport us from the easy, or extreme, cases of New York and San Francisco. We started from San Francisco and built east with railroad track, and started also from. New York, building a six-lane highway west. Our ability to travel in comfort near either terminus is no doubt valuable, but it obscures the incoherence of the system as a whole. What could possibly serve as a golden spike in such a case?

Other fields of inquiry have faced similar problems. Twentieth century physics has, for example, developed both a general relativity theory deploying and explaining large-scale gravitational effects, and a quantum theory to explain events at a much smaller scale of magnitude. The problem is that if we.want to understand the physics as a unified whole, we cannot just start at either the large-scale or the small-scale level, with the mathematical language developed for that level, and then work our way to the other end using that language. ${ }^{148}$ We cannot start with relativity and work our way down until we have neatly incorporated quantum phenomena, and we cannot apply quantum theory to larger and larger objects until we have encompassed massive gravitational effects. The languages involved are at present incommensurable, or mutually untranslatable. ${ }^{149}$

Similarly, we lack a seamless, unified, encompassing theory of moral rights, including human rights, and their application and

148. John D. Barrow, The Origin of the Universe 88-89 (Basic Books, 1994); Michael Lockwood, Mind Brain and the Quantum at 286-87. (Blackwell, 1990).

149. Id. 
overridability. In the absence of such a unified theory, it is tempting to subordinate either of the two languages, or paradigm cases. Thus one might reject any appeal to net consequences even in the catastrophic cases, ${ }^{150}$ or one might equally and oppositely try to set aside the traditional idea of human and other moral rights in favor of some sort of general utilitarian calculus. ${ }^{151}$

Neither of these alternatives would, however, really solve the problem. We can calmly invite moral catastrophe only on the basis of a logic that is difficult, at best, to publicly share and examine. And on the other hand, even the most thorough sort of consequentialism must involve considerations that look very much like moral rights: What sorts of beings count? Do we all count equally? We have seen how normative utilitarianism is driven in the direction of recognizing some sorts of moral rights in practice, as much to avoid unattractive outcomes as for sheer convenience in application. ${ }^{152}$ But we need some theory of when to endorse such "intuitive" rights, and what particular form they should take.

Moving in from the other direction, we might formulate unusually detailed and specific moral rights that try to limit their own scope by taking account of moral disasters, the motivation of the actor, moral character, and various particular circumstances. ${ }^{153}$ Thus we might conceivably endorse a moral rule that by its own terms allows lying, say, when the alternative would be nightmarish, when the lie actually reflects good character, when the lie builds good character in another or prevents further lies, when the truth is not really expected or is under attack by our audience, and so on. ${ }^{154}$ What we must do at this point is to offer some theory of where these more narrowly crafted, less risky rights are coming from. Are they

150. John Finnis, Moral Absolutes: Tradition, Revision, and Truth (CUA Press, 1991).

151. See, unequivocally and classically, Jeremy Bentham, The Utilitarians: An Introduction to the Principles of Morals and Legislation (Doubleday, 1961). For an instance of contemporary utilitarianism, see, for example, J.J.C. Smart \& Bernard Williams, Utilitarianism: For and Against 3 (Cambridge U Press, 1973).

152. See notes $89-92$ and accompanying text. For further discussion, see, for example, R. George Wright, What's Gone Wrong With Legal Theory?: The Three Faces of Our Split Personality 33 Wake Forest L Rev 371, 383 (1998).

153. Rescher, Objectivity at 167 (cited in note 133).

154. Id. 
not just ad hoc reflections of unsystematized moral sentiments? Are they not still just approximations? Must we not revise them to take account of new contingencies we had not previously thought of? Won't the most unimpeachable narrow rules also be the most uninformative; for example, "Don't lie to anyone for frivolous reasons?"

The golden spike problem, or something equally severe, thus remains a problem for anyone who does not reject normative ethics entirely. ${ }^{155}$ Until we solve this problem, however, we will not have a genuinely unified and complete theory of rights, or of the place of rights in a broader normative ethical system. ${ }^{156}$

155. One could, certainly, solve the problem at a merely verbal level by seeking to "maximize" both consequential value and nonconsequential values at stake in any given case. See Garth L. Hallett, Greater Good at 2 (cited in note 130). It remains to be seen how this would be worked out. For some relevant discussion, see Robert Audi, Moral Knowledge and Ethical Character 294-95 (Oxford U Press, 1997).

156. A possible first step would be to apply the idea of "reflective equilibrium" developed by writers such as John Rawls and Norman Daniels. See, for example, John Rawls, $A$ Theory of Justice 20, 48 (Belknap Press of Harv U Press, 1971); Norman Daniels, Wide Reflective Equilibrium and Theory Acceptance in Ethics 76 J Phil 256 (1979). Another possible first step would be to appeal somehow to the idea of Aristotelian phronesis or practical wisdom. See Robert Audi, Moral Knowledge at 294 (cited in note 155). For background, see, for example, Sarah Broadie, Ethics With Aristotle ch 4 (Oxford U Press, 1991); C.D.C. Reeve, Practices of Reason: Aristotle's Nicomachean Ethics ch 2 (Clarendon Press, 1995). For background discussion of the controversial relationship between utility and rights see, for example, Ian Shapiro, The Evolution of Rights in Liberal Theory ch 6 (Cambridge U Press, 1986) (arguing that the alleged gulf between liberal individual rights theory and utilitarianism is largely illusory); Alan Ryan, ed, The Idea of Freedom: Essays in Honour of Isaiah Berlin 77 (Oxford U Press, 1979) (emphasizing the disjunction between rights theory and utilitarianism); R.G. Frey, ed, Utility and Rights (U of Minn Press, 1984); Jeremy Waldron, ed, Utility and Rights in Theories of Rights 110 (Oxford U Press, 1984); David Lyons, Human Rights and the General Welfare 6 Phil \& Pub Aff 113 (1977); Gewirth, Human Rights at ch 5 (cited in note 142). 
